\title{
UJI AKTIVITAS EKSTRAK ETANOL JAHE MERAH (Zingiber officinale Rosc var rubrum) DALAM MEMPROTEKSI DAN MEMPERBAIKI GANGGUAN FUNGSI HATI DAN GINJAL TIKUS AKIBAT INDUKSI PARASETAMOL
}

\author{
Muhammad Taufiq Duppa, Yulia Yusrini Djabir, Mufidah Murdifin \\ Fakultas Farmasi, Universitas Hasanuddin, Makassar
}

\section{Kata Kunci :}

Jahe Merah (Zingiber officinale Rosc var rubrum), Parasetamol, hepatoprotektif, nefroprotektif. $\begin{array}{ll}\text { Masuk } & 06-02-2020 \\ \text { Revisi } & 07-08-2020 \\ \text { Diterima } & 20-08-2020\end{array}$

DOI: $10.20956 / \mathrm{mff} . v 24 i 2.9303$

Korespondensi

Yulia Yusrini Djabir

yuliayusrini@yahoo.com

Copyright

(C) 2020 Majalah Farmasi

Farmakologi Fakultas Farmasi Makassar

Diterbitkan tanggal

20 Agustus 2020

Dapat Diakses Daring Pada: http://journal.unhas.ac.id/index.php/mff

\section{ABSTRAK}

Jahe merah merupakan jenis rimpang yang banyak digunakan sebagai bahan obat tradisional di Indonesia. Penelitian ini bertujuan untuk mengevaluasi efek proteksi ekstrak rimpang jahe merah (Zingiber officinale Rosc var rubrum) terhadap gangguan fungsi hati dan ginjal yang disebabkan oleh toksisitas parasetamol berdasarkan parameter SGPT, SGOT, urea dan kreatinin serum pada tikus putih. Jahe merah diekstraksi menggunakan etanol $70 \%$. Hewan uji dibagi ke dalam 5 kelompok $(n=5)$. Kelompok I sebagai kontrol sehat diberikan suspensi NaCMC 1\%, kelompok II diberikan NaCMC 1\% dan induksi parasetamol, kelompok III dan kelompok IV masing-masing diberi perlakuan ekstrak jahe merah $150 \mathrm{mg} / \mathrm{kgBB}$ dan $300 \mathrm{mg} / \mathrm{kgBB}$ dan induksi parasetamol, dan kelompok $V$ diberikan sediaan ekstrak curcuma xanthorriza (60 mg/kgBB) dan induksi parasetamol. Perlakuan dilakukan selama 10 hari sedangkan induksi parasetamol hanya diberikan pada hari ke-4 $(500 \mathrm{mg} / \mathrm{kg}$ ) dan ke-5 $(300 \mathrm{mg} / \mathrm{kg})$. Sampel darah diambil pada hari ke- 6 (post induksi) dan ke-11 (post perlakuan) untuk pengukuran kadar SGOT, SGPT, kreatinin dan urea serum menggunakan alat humalyzer. Hasil penelitian menunjukkan pemberian parasetamol dosis $500 \mathrm{mg} / \mathrm{kg}$ diikuti $300 \mathrm{mg} / \mathrm{kgBB}$ dapat meningkatkan nilai SGOT dan SGPT secara signifikan 24 jam setelah post induksi, namun kadar urea dan kreatinin hanya berbeda signifikan setelah hari ke-11 (post perlakuan). Pada kelompok III dan IV, pemberian ekstrak jahe merah setelah induksi parasetamol mampu menurunkan kadar SGOT, SGPT, urea dan kreatinin serum secara signifikan dibanding kelompok II $(p<0.05)$. Penurunan biomarker hati dan ginjal pada kelompok III dan IV tidak berbeda signifikan dengan kelompok $V$ yang diberi sediaan ekstrak curcuma yang telah digunakan secara klinik.

\section{PENDAHULUAN}

Parasetamol atau asetaminofen merupakan salah satu analgesik antipiretik yang efektif menghilangkan rasa nyeri, menurunkan panas, tidak mengiritasi lambung dan banyak digunakan karena mudah didapatkan dan dijual tanpa harus dengan resep dokter. Parasetamol dimetabolisme di organ hati oleh enzim sitokrom P450 menjadi asetaminofen sulfat dan glukoronat. Namun, sekitar 5\% diekskresikan dalam bentuk metabolit reaktif yaitu $\mathrm{N}$-acetyl-p-benzoquinone Imine (NAPQI) yang diketahui bersifat hepatotoksik. Penimbunan NAPQI di hepar menyebabkan nekrosis pada sel hepatosit yang berkaitan dengan dosis paracetamol [1]. Pada pemakaian dosis yang tepat hepar dapat merubah NAPQI menjadi zat yang tidak toksik terhadap tubuh maupun sel hepatosit itu sendiri. Namun kemampuan hepar terbatas jika pemakaian parasetamol berlebihan maka NAPQI akan tertimbun di dalam hepar dan merusak sel-sel hepatosit. Selain itu NAPQI juga akan terlepas ke dalam darah sehingga dapat merusak sel-sel lain dalam tubuh termasuk sel nefron pada ginjal. Kerusakan pada ginjal tersebut ditandai oleh nekrosis tubulus akut disertai meningkatnya kadar ureum dan kreatinin plasma. Target utama dari nekrosis tubular akut pada kasus keracunan suatu zat adalah tubulus proksimal ginjal. Pada penelitian Botta dkk [2] disebutkan pemakaian parasetamol berlebihan menyebabkan cidera sel hepatosit yang fatal pada daerah sentrilobular dan nekrosis tubulus akut pada ginjal Adapun dosis yang direkomendasikan untuk parasetamol adalah tidak lebih dari 4 gram per hari untuk dewasa, dan maksimum $60 \mathrm{mg} / \mathrm{kg}$ per hari untuk anak-anak. Dosis parasetamol yang mengkibatkan toksisitas adalah 7,5-10g/hari [1].

Cidera pada sel hepatosit dapat ditandai dengan peningkatan Serum Glutamic Oxaloacetic Transaminase (SGOT) dan Serum Glutamic Piruvic Transaminase (SGPT) yang merupakan enzim transaminase hati. Peningkatan SGPT merupakan indikator yang lebih sensitif terhadap kerusakan hati dibanding SGOT karena sumber utama enzim GPT adalah sel hepatosit, sedangkan enzim GOT dapat juga diproduksi pada jaringan lain terutama jantung, otot rangka, ginjal dan otak. Kadar norrmal enzim SGOT dan SGPT mencerminkan keutuhan atau intergrasi sel-sel hati. Peningkatan kedua kadar kedua enzim tersebut dalam darah mengindikasikan terjadinya kerusakah sel-sel hati yang mengakibatkan keluarnya enzim tersebut masuk ke dalam darah. Semakin tinggi peningkatan kadar enzim SGOT dan SGPT, semakin tinggi pula tingkat kerusakan sel-sel hati [3]. 
Pencegahan kerusakan hati oleh parasetamol dapat dilakukan dengan mengkonsumsi bahan pangan atau tanaman yang memiliki khasiat efek protektif. Biasanya efek protektif merupakan bahan yang memiliki sifat antioksidan sehingga dapat mengurangi reaksi oksidasi pada kerusakan hati. Tumbuhan obat yang terbukti berkhasiat sebagai efek protektif contohnya kurkumin yang diperoleh dari rimpang temulawak atau kunyit. Senyawa kurkumin ditemukan berkhasiat bekerja melindungi hati dari kerusakan yang ditimbulkan oleh senyawa toksikan, mencegah inflamasi pada jaringan hati dan memperlambat progress karsinoma hati [4].

Jahe merah (Zingiber officinale var Rubrum) banyak digunakan di berbagai belahan dunia untuk bumbu masakan dan obat tradisional. Sama seperti jahe secara umum, jahe merah juga mengandung berbagai senyawa yang aktif secara biologi, terutama 6-gingerol, 6-shogaol, zingerone, phenolics, dan flavonoid [5]. Perbedaan jahe merah dari jahe yang lain adalah intensitas rasa pedas yang lebih tinggi dibanding dengan jenis jahe gajah dan jahe emprit. Diantara komponen yang diidentifikasi, 6-gingerol dilaporkan sebagai senyawa bioaktif yang paling melimpah pada jahe dengan berbagai efek farmakologis termasuk antioksidan, analgesik, antiinflamasi dan antipiretik $[6,7]$. Sebelumnya, ekstrak jahe telah diteliti memiliki efek hepatoprotektif dan antioksidan terhadap toksisitas parasetamol menggunakan dosis toksik $600 \mathrm{mg} / \mathrm{kg}$ [8]. Berdasarkan hal tersebut, penelitian ini bertujuan untuk mengeksplorasi lebih lanjut efek protektif jahe merah terhadap fungsi hati dan ginjal menggunakan indikator kadar SGPT, SGOT, urea dan kreatinin serum pada tikus putih.

\section{METODE PENELITIAN}

\section{Bahan Penelitian}

Rimpang jahe merah (Zingiber officinale var Rubrum), etanol $70 \%$, tikus putih galur wistar, Parasetamol, aquadest, Natrium Carboxyl Methyl Cellulose (Na CMC), Reagen SGPT (Human World Diagnostic, Germany) , Reagen SGOT (Human World Diagnostic, Germany), Reagen Urea (Human World Diagnostic, Germany), Reagen Kreatinin (Human World Diagnostic, Germany) dan ekstrak temulawak (Curcuma FCT).

\section{Penyiapan Sampel}

Sampel rimpang jahe merah diperoleh dari Dusun Palirang, Kelurahan Tonyamang, Kecamatan Patampanua, Kabupaten Pinrang Provinsi Sulawesi Selatan. Rimpang jahe merah dibersihkan dengan air mengalir, kemudian dipotong kecilkecil, lalu dikeringkan pada udara terbuka dan terlindung dari sinar matahari secara langsung.

\section{Prosedur Ekstraksi}

Sampel sebanyak 800 gram dimasukkan kedalam bejana maserasi kemudian sampel dibasahkan dan direndam dengan etanol $70 \%(1: 7,5)$ selama 5 hari sambil sesekali diaduk. Maserat dikumpulkan dan diuapkan dengan vacuum rotary evaporator dengan suhu $60^{\circ} \mathrm{C}$ dan dipekatkan diatas waterbath dengan suhu $60-70^{\circ} \mathrm{C}$ hingga diperoleh ekstrak kental.

\section{Prosedur Perlakuan}

Hewan coba berupa tikus wistar jantan dengan bobot 170230 gram dan dibagi kedalam 5 kelompok. Kelompok I yaitu kelompok kontrol, diberikan suspensi Na CMC dan diberi makan pelet biasa selama 10 hari. Kelompok II diberi NaCMC $1 \%$ selama 10 hari (kontrol negatif) dan mendapatkan induksi parasetamol pada hari ke-4 (500 mg/kg BB) dan hari ke-5 (300 mg/kg BB). Kelompok III diberi ekstrak jahe merah
$150 \mathrm{mg} / \mathrm{kg}$ BB diberikan selama 10 hari dan pada hari ke-4 dan ke-5 diinduksi dengan parasetamol. Kelompok IV diberi ekstrak jahe merah $300 \mathrm{mg} / \mathrm{kg}$ BB diberikan selama 10 hari dan pada hari ke-4 dan ke-5 diinduksi dengan parasetamol. Kelompok V diberi sediaan ekstrak temulawak $60 \mathrm{mg} / \mathrm{kg}$ BB selama 10 hari dan pada hari ke-4 dan ke-5 diinduksi dengan parasetamol. Pemberian perlakuan dilakukan 3 hari sebelum induksi parasetamol untuk melihat apakah perlakuan tersebut dapat mencegah peningkatan biomarker disfungsi hati dan ginjal, kemudian perlakuan dilanjutkan hingga hari ke-10 untuk melihat apakah perlakuan mampu menurunkan peningkatan biomarker hati dan ginjal setelah induksi parasetamol. Pengambilan darah dilakukan pada hari ke- 6 (24 jam setelah induksi parasetamol terakhir) dan hari ke-11 (5 hari setelah perlakuan terakhir).

\section{Pengambilan sampel darah hewan uji}

Sampel darah hewan uji dengan menggunakan spoit sebanyak $3 \mathrm{ml}$ melalui ekor dan ditampung dalam tabung vakum berisi EDTA. Darah disentrifus dengan kecepatan $1000 \mathrm{rpm}$ selama 15 menit untuk memisahkan serum dari sel darah. Serum diambil dan ditampung dalam tabung Eppendorf, lalu disimpan pada suhu $-20^{\circ} \mathrm{C}$ hingga dianalisis.

\section{Analisis kadar biomarker fungsi hati dan ginjal}

Analisis dilakukan menggunakan alat Humalyzer 3500 (Human World Diagnostic). Kondisi pemeriksaan diatur dengan celah optik $1 \mathrm{~cm}$, suhu $37^{\circ} \mathrm{C}$, panjang gelombang 400 $420 \mathrm{~nm}$. Reagen dan kuvet diinkubasi pada suhu yang dikehendaki dan suhu dijaga konstan $\left( \pm 0,5^{\circ} \mathrm{C}\right)$ selama tes. Parameter yang diukur berupa kadar SGOT, SGPT, Kreatinin dan Urea serum menggunakan kit diagnostik (Human World Diagnostic).

\section{Analisis data}

Data berupa mean \pm SEM. Data dianalisis dengan SPSS versi 20 for windows. Dilakukan uji normalitas data dengan Kolmogorov Smirnov. Data terdistribusi normal dilanjutkan dengan menggunakan One Way Analysis of Variance, lalu dilanjutkan dengan uji post hoc Tukey's HSD. Data dinyatakan signifikan bila $\mathrm{P}<0.05$.

\section{HASIL DAN PEMBAHASAN}

Evaluasi kerusakan hati, dapat dilakukan melalui pemeriksaan berbagai enzim serum terutama SGPT dan SGOT. Kedua enzim tersebut merupakan petunjuk dinin adanya cedera sel hati. Secara fisiologis, enzim GPT dan GOT mengkatalis pemindahan gugus amino, terdapat banyak di hepatosit dan konsentrasinya relatif rendah di jaringan lain [9]. Bila jaringan hati mengalami kerusakan akut, kadar GPT dan GOT dalam serum meningkat. Diduga hal ini disebabkan oleh terlepasnya enzim intraseluler dari sel-sel yang rusak ke dalam sirkulasi. Kadar yang sangat meningkat terdapat pada nekrosis hepatoseluler atau infark miokard [10].

Pada penelitian ini digunakan parasetamol sebagai agen penginduksi kerusakan hati. Metabolisme hepatik parasetamol melalui jalur enzim sitokrom P-450 menghasilkan metabolit reaktif yang bersifat eletrofilik yang disebut NAPQI. Sitokrom P-450 yang paling berperan dalam metabolisme ini adalah CYP2E1. Meskipun enzim P-450 yang lain (seperti CYP3A4 dan CYP3A2) ikut berperan, namun beberapa studi farmakologi menunjukan bahwa peranannya tidak sebesar CYP2A1 [11]

Pada kondisi normal, metabolit ini diinaktivasi oleh glutation dengan atau tanpa melibatkan enzim glutation reduktase. Pada keracunan parasetamol cadangan glutation dengan cepat menurun. Hal ini menyebabkan timbulnya akumulasi NAPQI di dalam hepatosit dan membentuk ikatan kovalen 
dengan protein sel hepatosit, menghambat metabolisme oksidatif dan produksi ATP. Penurunan ATP intraseluler menyebabkan gangguan pompa kalsium endoplasma dan membran plasma, sehingga terjadi akumulasi kalsium di dalam sitoplasma. Akumulasi kalsium sitoplasma menyebabkan peningkatan aliran $\mathrm{Ca}^{2+}$ ke dalam mitokodria, penurunan potensial membran mitokodria dan menghambat sintesis ATP di mitokondria. Selain itu hipekalsemia intraseluler turut berperan memacu peningkatan produksi senyawa oksigen reaktif (reactive oxygen species, ROS) dan nitrogen reaktif (reactive nitrogen species, RNS). Hal inilah yang menyebabkan pemberian parasetamol dengan dosis tinggi seperti $300 \mathrm{mg} / \mathrm{kg}$ selama 2 hari dapat mengakibatkan kerusakan hati pada tikus putih [12].

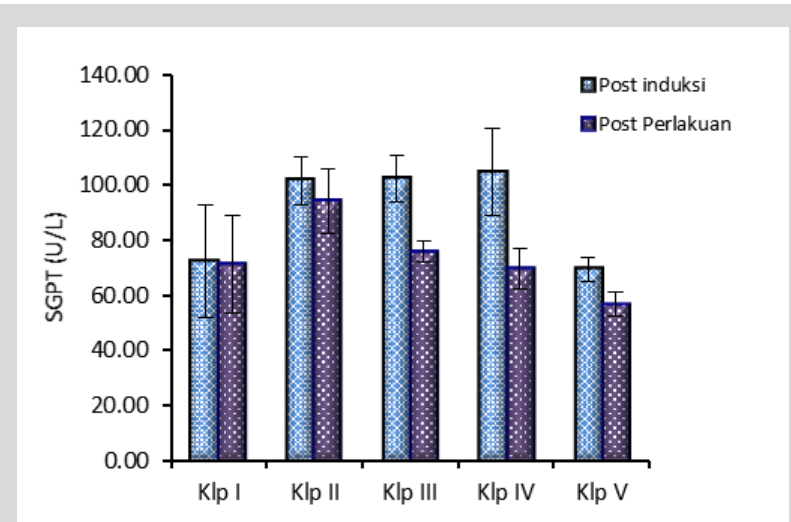

Gambar 1. Kadar SGPT tikus pada hari ke-6 (post induksi) dan hari ke11 (post perlakuan).

$\# p<0,05$ dibanding KIp II post induksi, * $p<0,05$ dibanding KIp II post perlakuan KIp I: NaCMC

KIp II: NaCMC, Parasetamol 500, $300 \mathrm{mg} / \mathrm{kg}$

KIp III: Ekstrak jahe $150 \mathrm{mg} / \mathrm{kg}$, Parasetamol 500, $300 \mathrm{mg} / \mathrm{kg}$

KIp IV: Ekstrak jahe $300 \mathrm{mg} / \mathrm{kg}$, Parasetamol 500, $300 \mathrm{mg} / \mathrm{kg}$

KIp V: Ekstrak kunyit $60 \mathrm{mg} / \mathrm{kg}$, Parasetamol 500, $300 \mathrm{mg} / \mathrm{kg}$

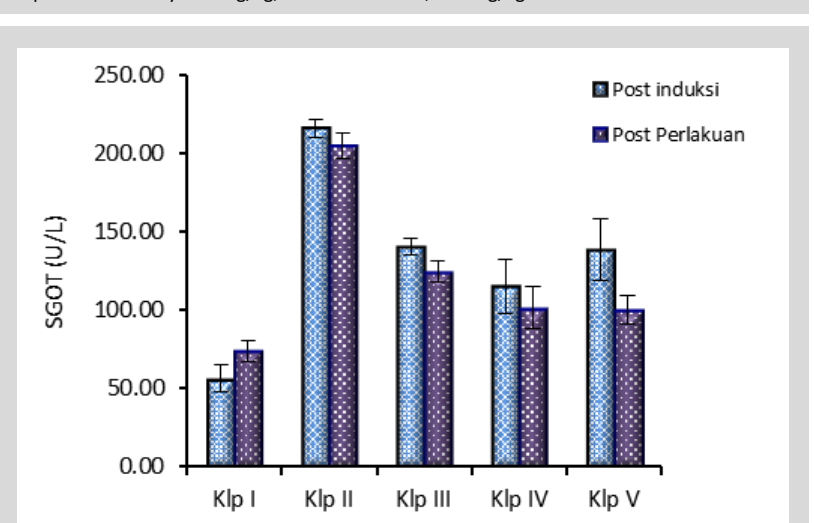

Gambar 2. Kadar SGOT tikus pada hari ke-6 (post induksi) dan hari ke-11 (post perlakuan)

$\# p<0,05$ dibanding KIp II post induksi, ${ }^{*} p<0,05$ dibanding KIp II post perlakuan KIp I: NaCMC

KIp II: NaCMC, Parasetamol 500, $300 \mathrm{mg} / \mathrm{kg}$

KIp III: Ekstrak jahe $150 \mathrm{mg} / \mathrm{kg}$, Parasetamol 500, $300 \mathrm{mg} / \mathrm{k}$

KIp IV: Ekstrak jahe $300 \mathrm{mg} / \mathrm{kg}$, Parasetamol 500, $300 \mathrm{mg} / \mathrm{kg}$

Klp V: Ekstrak kunyit $60 \mathrm{mg} / \mathrm{kg}$, Parasetamol 500, $300 \mathrm{mg} / \mathrm{kg}$

Dalam penelitian ini, induksi parasetamol meningkatkan kadar SGPT pada kelompok II yang hanya diberi pembawa hingga 30\% dari kadar SGPT tikus kontrol sehat $(p<0.05)$ pada hari ke-6 (lihat Gambar 1). Kadar SGPT tikus kelompok II bertahan di atas kadar SGPT tikus sehat hingga hari ke-11. Berbeda dengan tikus kelompok I, tikus kelompok III dan IV juga mengalami peningkatan SGPT pada hari ke-6 setelah induksi parasetamol yaitu sebesar 102,23 $\pm 8,64$ dan $104,61 \pm 15,82 \mathrm{IU} / \mathrm{L}$ dibandingkan 72,29 $\pm 20,22 \mathrm{IU} / \mathrm{L}$ pada tikus kontrol sehat. Namun setelah pemberian perlakuan ekstrak jahe merah lebih lanjut, pada hari ke-11 kadar SGPT kedua kelompok turun dari 102,22 $\pm 8,64$ IU/L menjadi $75,8 \pm 3.71$ IU/L pada kelompok III dan 104,61 $\pm 15,82 \mathrm{IU} / \mathrm{L}$ menjadi 69,64 \pm 3.71 IU/L pada kelompok IV. Dari kelompok perlakuan, hanya kelompok $\mathrm{V}$ yang diberi sediaan ekstrak temulawak yang tidak mengalami kenaikan SGPT pada hari ke-6 $(69,46 \pm 8,44$ IU/L) maupun ke-11 $(56,60 \pm 8,79$ IU/L) walaupun diberi induksi parasetamol. Hal ini menunjukkan bahwa ekstrak temulawak efektif dalam mencegah dan mengobati kelainan fungsi hati pada tikus putih akibat pemberian parasetamol dosis tinggi.

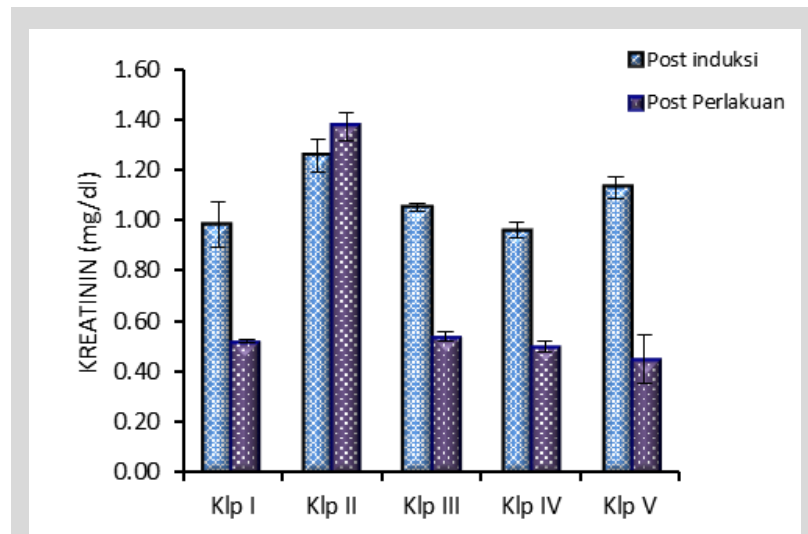

Gambar 3. Kadar kreatinin serum tikus pada hari ke-6 (post induksi) dan hari ke-11 (post perlakuan).

$\# p<0,05$ dibanding KIp II post induksi, ${ }^{*} p<0,05$ dibanding KIp II post perlakuan KIp I: NaCMC

KIp II: NaCMC, Parasetamol 500, $300 \mathrm{mg} / \mathrm{kg}$

KIp III: Ekstrak jahe $150 \mathrm{mg} / \mathrm{kg}$, Parasetamol 500, $300 \mathrm{mg} / \mathrm{kg}$ KIp IV: Ekstrak jahe $300 \mathrm{mg} / \mathrm{kg}$, Parasetamol 500, $300 \mathrm{mg} / \mathrm{kg}$ Klp V: Ekstrak kunyit $60 \mathrm{mg} / \mathrm{kg}$, Parasetamol 500, $300 \mathrm{mg} / \mathrm{kg}$

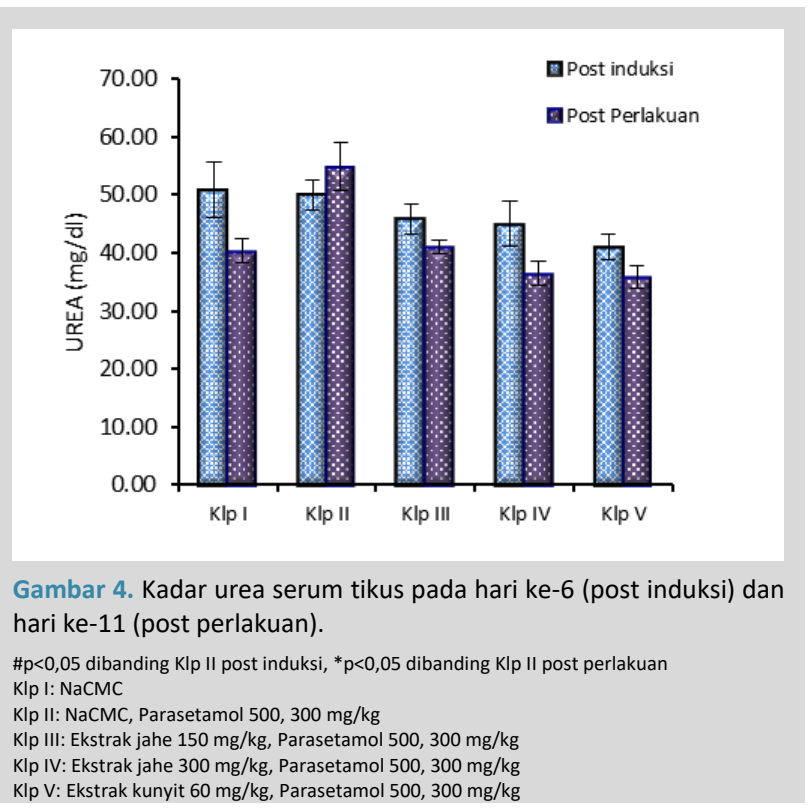

Gambar 2 menunjukkan hasil pengukuran SGOT setelah hari ke-6 dan ke-11. Pengukuran SGOT pada kelompok yang hanya diinduksi parasetamol tanpa perlakuan ekstrak juga menunjukkan peningkatan yang signifikan dibanding kelompok kontrol sehat $(56,29 \pm 8.73 \mathrm{IU} / \mathrm{L})$. Bahkan, peningkatan SGOT pada kelompok II lebih 3.5 kali lipat nilai SGOT pada kelompok I mulai hari ke-6 $(216,28 \pm 5,95$ IU/L) hingga hari ke-11 $(204,84 \pm 8,07$ IU/L). Pemberian ekstrak jahe merah 3 hari berturut-turut sebelum induksi parasetamol dapat mengurangi peningkatan SGOT secara signifikan pada hari ke-6, dimana SGOT kelompok III adalah $140,74 \pm 5,57$ IU/L dan kelompok IV mencapai 115,13 $\pm 17,39$ IU/L. Bahkan, nilai SGOT terus turun pada kelompok III dan IV hingga hari ke-11. Hal yang serupa terlihat dengan pemberian sediaan ekstrak temulawak, dimana pada hari ke6 SGOT kelompok V adalah 138,66 $\pm 19,48$ IU/L dan turun menjadi 100,36 $\pm 8,87 \mathrm{IU} / \mathrm{L}$ pada hari ke-11. Kadar urea tikus kelompok II pada hari ke-11 terlihat lebih tinggi dibanding kelompok I $(54,83 \pm 84,15$ vs $40,38 \pm 2,13 \mathrm{mg} / \mathrm{dl}, \mathrm{p}<0.05)$. 
Sedangkan, pemberian ekstrak jahe merah maupun sediaan ekstrak temulawak mampu mempertahankan kadar urea serum tikus pada range $35,87 \pm 1,96$ hingga $41,09 \pm 1,23 \mathrm{mg} / \mathrm{dl}$ (Gambar 4).

Dari hasil penelitian dapat terlihat bahwa induksi parasetamol dosis $500 \mathrm{mg} / \mathrm{kg}$ dan $300 \mathrm{mg} / \mathrm{kg}$ dalam 2 hari pemberian dapat meningkatkan kadar SGOT, SGPT, kreatinin dan urea serum. Hal ini menandakan bahwa dengan dosis tersebut, parasetamol tidak hanya menyebabkan kerusakan sel hepatosit, tetapi juga sel nefron ginjal. Kreatinin dan urea serum merupakan molekul yang seharusnya dapat difiltrasi secara bebas oleh glomerulus, sehingga peningkatan kadar kreatinin dan urea dalam darah dapat menjadi parameter terganggunya fungsi filtrasi glomerulus. NAPQI yang merupakan metabolit parasetamol mampu berikatan secara kovalen dengan makromolekul vital (lipid dan protein membrane) sehingga menyebabkan kerusakan hati dan organ lain, termasuk ginjal [13].

Salah satu mekanisme yang mungkin memediasi efek perbaikan pada fungsi hati dan ginjal setelah pemberian ekstrak jahe merah adalah adanya senyawa yang bersifat antiinflamasi dan antioksidan dalam ekstrak jahe merah. Kandungan jahe merah terutama adalah gingerol dan shogaol. Telah banyak penelitian yang menunjukkan bahwa baik gingerol maupun shogaol memiliki aktivitas antioksidan. Dugasani et al (2010) menunjukkan bahwa senyawa 6gingerol dari jahe merah yang paling efektif menghambat radikal bebas DPPH dibandingkan 8-gingerol, 10-gingerol, dan 6-shigaol [14]. Sedangkan, untuk efek antiinflamasi, potensi shigaol dinyatakan lebih baik dalam mengurangi aktivitas mediator proinflamasi [15]. Dikemukakan bahwa, efek antiinflamasi senyawa gingerol, shogaol, dan senyawa lain dalam jahe yang mirip secara struktural mampu menghambat prostaglandin dan biosintesis leukotrien melalui penekanan 5-lipoksigenase atau prostaglandin sintetase [16].

Antioksidan dapat menurunkan kerusakan oksidatif secara langsung melalui reaksi dengan radikal bebas atau secara tidak langsung dengan menghambat aktivitas atau ekspresi enzim pembangkit radikal bebas atau meningkatkan aktivitas atau ekspresi enzim antioksidan intraseluler [17]. Bahan aktif jahe merah yang berperan sebagai antioksidan termasuk golongan senyawa fenol. Senyawa fenol memiliki kemampuan dalam menstabilkan radikal bebas, yaitu dengan memberikan atom hidrogen secara cepat kepada radikal bebas. Gingerol, shagaol, dan zingerone memiliki aktivitas antioksidan yang serupa dengan vitamin E [8]. Bahkan, terdapatnya beberapa antioksidan dalam ekstrak jehe merah seperti flavonoid, kurkumin, vitamin C dan E kemungkinan saling mempotensiasi untuk meredam akibat kelebihan radikal bebas di dalam tubuh.

\section{KESIMPULAN}

Berdasarkan penelitian yang telah dilakukan dapat ditarik kesimpulan bahwa pemberian ekstrak jahe merah dengan dosis $150 \mathrm{mg} / \mathrm{kg} \mathrm{BB}$ dan $300 \mathrm{mg} / \mathrm{kg}$ BB secara oral ke tikus putih efektif menurunkan kadar SGPT, SGOT, kreatinin dan urea serum yang di induksi parasetamol dosis toksik.

\section{DAFTAR PUSTAKA}

1. Agrawal S and Khazaeni B, Acetaminophen toxicity. In: Statpearls [internet]. 2020, StatPearls Publishing: Treasure Island (FL). //http://www.ncbi.nlm.nih.gov/books/NBK441917/.

2. Botta D, Shi S, White CC, Dabrowski MJ, Keener CL, Srinouanprachanh SL, et al. Acetaminophen-induced liver injury is attenuated in male glutamate-cysteine ligase transgenic mice. Journal of Biological Chemistry 2006; 281(39): 28865-28875.

3. Bhakuni GS, Bedi O, Bariwal J, Deshmukh R, and Kumar P. Animal models of hepatotoxicity. Inflammation Research 2016; 65(1): 13-24.

4. Nabavi SF, Daglia M, Moghaddam AH, Habtemariam S, and Nabavi SM Curcumin and liver disease: From chemistry to medicine. Comprehensive Reviews in Food Science and Food Safety 2014; 13(1): 62-77.

5. Ha SK, Moon E, Ju MS, Kim DH, Ryu JH, Oh MS, et al. 6-shogaol, a ginger product, modulates neuroinflammation: A new approach to neuroprotection. Neuropharmacology 2012; 63(2): 211-223.

6. Suekawa M, Ishige A, Yuasa K, Sudo K, Aburada M, and Hosoya E. Pharmacological studies on ginger. I. Pharmacological actions of pungent constituents,(6)-gingerol and (6)-shogaol. Journal of pharmacobiodynamics 1984; 7(11): 836-848.

7. Peng F, Tao Q, Wu X, Dou H, Spencer S, Mang C, et al. Cytotoxic, cytoprotective and antioxidant effects of isolated phenolic compounds from fresh ginger. Fitoterapia 2012; 83(3): 568-585.

8. Abdel-Azeem AS, Hegazy AM, Ibrahim KS, Farrag A-RH, and El-Sayed EM Hepatoprotective, antioxidant, and ameliorative effects of ginger (zingiber officinale roscoe) and vitamin e in acetaminophen treated rats. Journal of dietary supplements 2013; 10(3): 195-209.

9. Giannini EG, Testa R, and Savarino V. Liver enzyme alteration: A guide for clinicians. Cmaj 2005; 172(3): 367-379.

10. Hall $P$ and Cash J. What is the real function of the liver 'function'tests? The Ulster medical journal 2012; 81(1): 30.

11. Hinson JA, Roberts DW, and James LP, Mechanisms of acetaminopheninduced liver necrosis, in Adverse drug reactions. 2010, Springer. p. 369405.

12. Larson AM. Acetaminophen hepatotoxicity. Clinics in liver disease 2007; 11(3): 525-548.

13. Mazer $M$ and Perrone J. Acetaminophen-induced nephrotoxicity: Pathophysiology, clinical manifestations, and management. Journal of Medical Toxicology 2008; 4(1): 2-6.

14. Dugasani S, Pichika MR, Nadarajah VD, Balijepalli MK, Tandra S, and Korlakunta JN. Comparative antioxidant and anti-inflammatory effects of [6]-gingerol,[8]-gingerol,[10]-gingerol and [6]-shogaol. Journal of ethnopharmacology 2010; 127(2): 515-520.

15. Sang S, Hong J, Wu H, Liu J, Yang CS, Pan M-H, et al. Increased growth inhibitory effects on human cancer cells and anti-inflammatory potency of shogaols from zingiber officinale relative to gingerols. Journal of agricultural and food chemistry 2009; 57(22): 10645-10650.

16. Mashhadi NS, Ghiasvand R, Askari G, Hariri M, Darvishi L, and Mofid MR. Anti-oxidative and anti-inflammatory effects of ginger in health and physical activity: Review of current evidence. International journal of preventive medicine 2013; 4(Suppl 1): S36.

17. Lü JM, Lin PH, Yao Q and Chen C. Chemical and molecular mechanisms of antioxidants: Experimental approaches and model systems. Journal of cellular and molecular medicine 2010; 14(4): 840-860 